\title{
COMPENSATION OF PERSONS ERRONEOUSLY CONFINED BY THE STATE
}

In the summer of 1966, a university professor's wife was raped in Philadelphia. Gordon J. Ragan was convicted and imprisoned on the strength of an identification by the victim. After serving three years, Ragan was released when another young man, to whom Ragan bore startling resemblance, confessed to the crime. ${ }^{1}$ Ragan's response to his release was: "[I]f it happened to me it must have happened to thousands of other people." 2

In 1932, Professor Edwin Borchard presented case studies of 65 similar victims of erroneous confinements by the state. ${ }^{3}$ He remarked then that " $[\mathrm{I}] \mathrm{t}$ seems strange that so little attention has been given to one of the most flagrant of all publicly imposed wrongs-the plight of the innocent victim of unjust conviction in criminal cases." 4 Professor Borchard's observation could be made with equal force today: in the overwhelming number of cases no adequate relief is available to those, like Gordon Ragan, erroneously confined by state criminal processes.

Erroneous criminal conviction is not the only route to unjust incarceration. Errors in the civil commitment context are adequately suggested by the report of the recent release of Catherine Sinschuck, a Ukrainian woman believed insane and confined in the Philadelphia Hospital at Byberry for forty-eight years-largely because she could not speak English. ${ }^{5}$ Redress for victims of erroneous civil commitment is also generally unavailable or inadequate.

Tremendous strides have been made in recent decades toward protecting the rights of one accused of a crime. More recently, attention has focused on such matters as the remedies available to persons injured while imprisoned, ${ }^{6}$ and compensation for victims of crime $^{7}$ and mob violence. ${ }^{8}$ Protective rules have been developed to guarantee the rights of persons civilly confined through exclusively

I See Phila. Sunday Bulletin, Feb. 16, 1969, at 1, col. 1.

$2 I d$.

3 E. Borchard, Convicting the Innocent (1932).

4 Id. 375.

5 See Phila. Evening Bulletin, Dec. 18, 1969, at 1, col. 1.

6See, e.g., Note, Remedies Available to Penal Immates for Injuries Received While Incarcerated, 34 InD. L.J. 609 (1959).

TSee, e.g., Childres, Compensation for Criminally Inflicted Personal Injury, 39 N.Y.U.L. REV. 444 (1964); Rothstein, State Compensation for Criminally Infilcted Injuries, 44 Texas L. Rev. 38 (1965) ; Comment, Compensation for Victins of Crime, 33 U. CHI. L. REV. 531 (1966).

8 See, e.g., Note, Municipal Tort Liability: Statutory Liability of Municipalities for Danage Caused by Mobs and Riots, 50 CORNELL L.Q. 699 (1965). 
civil proceedings ${ }^{9}$ or following acquittal of a criminal charge. ${ }^{10}$ Yet for those erroneously confined by the power of the state-that is, confined following a legitimate criminal or civil proceeding marred by a mistake of fact ${ }^{11}$ - the opportunities for redress remain meager. The interests of these victims have received only passing attention ${ }^{12}$ since Professor Borchard's writings. ${ }^{13}$

This Comment will urge that when the exercise of state power results in an erroneous confinement, the government whose police power made such confinement possible should to the extent feasible redress the victim's injury, regardless of whether any government agent has played a culpable role. Recommended is redress in the form of monetary compensation, based on a "strict enterprise liability" rather than an "eminent domain" theory. Both rationales for compensation rest on the identical premise that erroneous confinements are costs of operation to be borne by the system; ${ }^{14}$ but the eminent domain

- See, e.g., Comment, Due Process for All-Constitutional Standards for Involumtary Civril Commitment and Release, 34 U. CHr. L. Rev. 633 (1967); Comment, The Nere Mental Health Codes: Safeguards in Compulsory Commitment and Release, 61 Nw. U.L. REV. 977 (1967).

${ }^{10}$ See, e.g. . Comment, Commitment Following Acquittal by Reason of Insanity and the Equal Protection of the Lazes, 116 U. PA. L. REv. 924 (1968).

11 An individual who in fact satisfies the substantive standards for a valid conviction or commitment, yet is subsequently released because of an error in applying one of the standards of confinement, would not be considered the victim of an erroneous confinement. Standards usually procedural in nature may have been misapplied, but the individual satisfied the substantive elements for confinement-he committed the crime for the purposes of legal proof. For example, a man released on a constitutional ground-such as admission of illegally seized evidence at trial-would not be considered a victim of an erroneous confinement if he in fact had committed the offense charged.

12 For an abbreviated statement of several statutes designed to provide monetary relief for persons erroneously convicted, see Note, Postrelease Remedies for Wrongful Conviction, 74 HARv. L. REv. 1615, 1626-27 (1961). The Note emphasizes remedies designed to insure the release of an innocent prisoner, and pays little attention to postrelease rehabilitation.

In the area of foreign and comparative law, much more has been written on the responsibility of the government for injuries caused to its citizens through the normal operation of governmental activities. On the specific problem of erroneous confinements, see Bratholm, Compensation of Persons Wrongfully Accused or Convicted in Norway, 109 U. PA. L. REv. 833 (1961). For a more generalized examination of foreign governmental responsibility for injuries caused by normal governmental activities, see authorities cited note 138 infra.

Most general commentary in recent years on governmental liability has been concerned essentially with fault-based tort liability, not with strict or absolute liability. See authorities cited notes 61 \& 96 infra.

13 Professor Borchard's outstanding writings on compensation of persons erroneously confined include (in chronological order): Borchard, European Systems of State Indemnity for Errors of Criminal Justice, 3 J. CRTM. L.C. 684 (1913); Borchard, Govermmental Liability [Responsibility] in Tort, 34 Y ALE L.J. 1, 129, 229 (1924), 36 YALE L.J. 1, 757, 1039 (1926), 28 CoLuM. L. ReV. 577, 734 (1928) (this was Borchard's eight-part treatise); E. BORCHARD, supra note 3 ; Borchard, State Indemnity for Errors of Criminal Justice, 21 B.U.L. REv. 201 (1941).

14 Professor Borchard attempted to set forth two separate theories to justify compensation. The first was the "eminent domain" theory wherein the taking of an individual's freedom for the preservation of peace through the administration of the criminal law is analogized to the taking of property for a public use. "Eminent domain," however, was apparently not used in the strict constitutional sense. Thus the theory seems to have intended a persuasive impact upon legislatures rather than a mandatory effect, although the term has been used by Borchard in such a context as 
thesis raises a specter of technical obstacles to recovery obfuscating the more immediate issue of redress. ${ }^{15}$

\section{Sources of Error: The State's Responsibility}

Erroneous confinements result most frequently from criminal proceedings. Precise empirical data is lacking; there is no way of knowing how many confinements were or are the product of error. Examination of various situations conducive to erroneous confinement, however, may help to identify the scope of the problem.

The largest number of erroneous criminal incarcerations results from erroneous arrests. ${ }^{16}$ Participating agencies in 1968 reported $1,047,220$ arrests for major (index) offenses ${ }^{17}$ of court prosecutions stemming from these arrests, a significant portion resulted in acquittal or dropped charges. ${ }^{18}$ Undoubtedly some and possibly many of these cases of acquittal or dropped charges represent erroneous confinements. ${ }^{19}$

might imply either meaning. See text accompanying note 163 infra ("eminent domain" in the nonconstitutional sense); Borchard, State Indemnity for Errors of Criminal Justice, 21 B.U.L. REv. 201, 207 (1941) (implying what might be the constitutional argument, though still probably used only for its persuasive effect by way of analogy).

The second theory, which might be called the strict liability theory, or as Professor Borchard would call it, the "social welfare" theory, implies that when any great undertaking, such as the administration of the criminal laws, results in error, those who derive the benefit of such an undertaking-society in general-should share the loss incurred by the victim of that error. Id. 208 .

Both foregoing theories involve a quid pro quo whereby the state would offer compensation in exchange for a necessary deprivation of the freedom of certain men-necessary to the extent that errors are an inherent part of the system. It is irrelevant whether one speaks in terms of the "risk" of erroneous confinement, or of the act of confinement as a "taking." The transaction would be the same regardless of the terminology-erroneous loss of freedom traded for compensation.

15 The theory of "eminent domain" often connotes a constitutional mandate to compensate. See, e.g., U.S. CoNST. amend. V. A theory of compensation resting upon a constitutional basis encounters substantial problems, not the least of which is the almost complete absence of precedent to support application of such a theory to erroneous confinements. This is due in part to restrictive definitions of "property" for eminent domain purposes and the notion that the government should receive tangible benefit from the taking. See Note, supra note 12, at 1627. See generally Comment, Traps for the Unwary-The Problems in Seeking Injunctive or Monetary Relief from an Uncompensated Taking by the Federal Government, 46 NEB. L. REv. 816 (1967).

Failure to discuss a constitutional basis mandating compensation for erroneous confinements is not intended as a final rejection of such an argument. Indeed, those persons erroneously confined might allay the fear of unrestricted liability by providing the courts with a sufficiently well-defined class of plaintiffs and thus inspire serious consideration of a constitutionally based ground for compensation.

16 See Hall, Police and Law in a Democratic Society, 28 IND. L.J. 133, 152, 154 (1953) (estimates several million illegal arrests annually); Warner, Investigating the Law of Arrest, 26 A.B.A.J. 151 (1940).

17 U.S. FED. BUr. of Investigation, 1968 UnIform Crime Reports 109-148. The statistics that follow are based upon the reports of 4,812 agencies representing an estimated $145,306,000$ in population. See id. Table 22 , at 110 . Index offenses include criminal homicide, forcible rape, robbery, aggravated assault, burglary, larceny, and auto theft. Id. 57 .

18 Of the total arrests reported for index offenses, 369,703 were adults. Id. 117, 118 (by subtraction of offenses). Of these, $88 \%$ were prosecuted in the courts and of those so prosecuted $28 \%$ were either acquitted or their charges dropped. Id. 34, 35.

19 Persons confined before trial and later acquitted (or whose charges are dropped) may not be victims of erroneous confinements (for compensatory purposes) because although the state could not gain a conviction or elected not to prosecute, they may have in fact committed the offense charged and thus deserve no redress. 
The most serious and best known ${ }^{20}$ cases of erroneous confinement result from the conviction of the innocent. ${ }^{21}$ Some of the more common factors known to have been responsible for persuading the finder of fact of the guilt of an innocent man include misidentification, ${ }^{22}$ circumstantial evidence, ${ }^{23}$ frame-ups, ${ }^{24}$ overzealous police or prosecutors, ${ }^{25}$ prior convictions or unsavory records, ${ }^{26}$ community opinion demanding a conviction, ${ }^{27}$ and unreliability of expert evidence. ${ }^{28}$ In addition, erroneous convictions result from guilty pleas and confessions by innocent persons, ${ }^{29}$ or from the use of a false alibi by an innocent accused. ${ }^{30}$

A wide assortment of procedural errors violate constitutional guarantees to a fair trial and thus may support the overturning of a conviction by habeas corpus or other postconviction remedy. ${ }^{31}$ These constitutional errors usually focus upon the fairness of the trial; thus release does not prove innocence, but simply that the conviction was constitutionally unacceptable. Nonetheless, constitutional errors may be a significant cause of convictions of individuals in fact innocent.

Other erroneous confinements are related to criminal proceedings yet are not literally the result of convicting the innocent. A law upon which a conviction is based may be subsequently repealed or declared invalid, raising the question whether the confinement should be deemed erroneous for purposes of compensation. ${ }^{32}$ Pretrial detention of wit-

20 For case histories of notable examples, see E. BorCHARD, supra note 3.

21 The term "not guilty" for criminal law purposes may hold a significantly different import from the term "innocent" in a compensatory scheme. The release of a prisoner either before or after trial may reflect a determination that the prisoner did not in fact commit the crime charged; but it also may mean that there was merely insufficient proof for a conviction, although as a matter of probability one could reasonably conclude that the defendant had committed the offense. However, the term "innocent" for compensatory purposes requires either a finding that the prisoner did not in fact commit the crime, or a high degree of probability that such is the case.

22 For examples of the operation of this type of error, see E. BoRCHARD, supra note 3 , at $x x y$ n.1. In one case, 17 witnesses mistakenly "identified" the wrong man. Id. 3.

23 Id. xxv nn.9-13.

24 Id. xxvi n. 15.

25 Id. xxvi nn.17 (police) \& 20 (prosecutors).

28 Id. xxvi n.21.

27 Id. xxvi n.25.

28 Id. xxvii n.31.

29 Myhre, Conviction Without Trial in the United States and Norway: $A$ Comparison, 5 Houston L. REv. 647 (1968). This phenomenon has received the following explanation:

For some, the drive for publicity may lead to a "confession"; others may be ridden by a pathological guilt complex; and in other instances the "confession" may be prompted by a wish to cover up another crime or to shield a friend or relative The practice of offering leniency for guilty pleas has created an additional factor of uncertainty, as there is some risk that an innocent person may plead guilty rather than risk a higher penalty should he be convicted.

Id. 651 (footnotes omitted).

30 E. BorCHARD, supra note 3 , at xxvii n.38.

31 For a concise checklist of constitutional contentions often asserted in habeas corpus proceedings, see R. Sokor, FEDERAL HABEAS CoRPUS 341-43 (2d ed. 1969).

32 See Field, The Effect of an Unconstitutional Statute in the Law of Public Officers: Liability of Officer for Action or Nonaction, 77 U. PA. L. REv. 155 (1928). 
nesses $^{33}$ and errors in computing a prisoner's sentence ${ }^{34}$ also provide possibilities for mistaken incarceration.

Erroneous confinements resulting from civil commitment proceedings may occur when an individual's mental deficiencies (apart from those related to the use of alcohol or drugs) lead to involuntary, ${ }^{35}$ temporary (protective), ${ }^{36}$ or voluntary ${ }^{37}$ commitment to state mental hospitals. Alcoholics and drug addicts are subject to commitment under somewhat different standards. ${ }^{38}$ Even the most innocuous of commitment procedures may lead to grievous consequences-such as the detainment of a man who had voluntarily committed himself but was unaware that requests for release were required in writing. ${ }^{39}$

Remedies for erroneous confinements might be sought against the government agent whose culpable ${ }^{40}$ act precipitated the error-but this

33 See Comment, Pretrial Detention of Witnesses, 117 U. PA. L. Rev. 700 (1969).

34 In one exceptional case, the prisoner was granted recovery for an error of parole authorities in computing his sentence. White v. State, 199 Misc. 728, 101 N.Y.S.2d 702 (1950).

35 E.g. Conn. Gen. Stat. Ann. \$17-177 (1958); Mich. Conp. Laws Ann. $\$ 330.18$ (1967); VA. Code ANN. \$37.1-66 (Supp. 1968); Wast. Rev. Code ANN. $\$ 71.02 .240$ (1962). For a treatment of some of the special risks involved in the procedures for commitment following acquittal for reasons of insanity, see Greenwald, Disposition of the Insane Defendant After "Acquittal"-The Long Road From Commitunent to Release, 59 J. CRIMr. L. \& CRIM. 583 (1968); Comment, supra note 10.

36 E.g., Conn. Gen. Stat. Ann. \$\$17-178, 17-183 (Supp. 1969) ; Mice. Comp. Laws AnN. \$330.19 (Supp. 1969); VA. Code ANN. \$37.1-69 (Supp. 1968); WasH. Rev. Code ANN. $\$ 71.03 .040$ (1962).

37 Many statutes provide for periods of varying lengths of confinement after the patient has requested release, and thus may result in the involuntary confinement of a person after his initial willing commitment. See, e.g., Mass. ANn. Laws ch. 123, \$ 86 (Supp. 1969) (involuntary confinement for up to 3 days after request for release) ; VA. CoDE ANN. \$\$37.1-65, 37.1-79 (Supp. 1968) (patient should be released within 15 days of request, but may at the superintendent's direction be retained for further treatment on an involuntary basis). Even a voluntary commitment statute providing that the patient is free to leave at any time after admission may lead to an erroneous confinement if the patient is not informed of the requisite procedures for release. See Conn. Gen. Stat. Ann. \$17-187 (Supp. 1969) ; cf. Roberts v. Paine, 124 Conn. 170, 199 A. 112 (1938).

38 Statutes for involuntary confinement of drug addicts are not unusual. See, e.g., Conn. Gen. Stat. Ann. \$ 17-185 (1960); Mich. Comp. Laws Ann. \$330.18 (1967); WASH. REv. CODE ANN. $\$ 72.48 .030$ (1962). Some statutes provide for a voluntary commitment including a period of involuntary confinement following the inmate's request for release. See, e.g., N.Y. MENTAL HYGIENe LaW \&306 (McKinney Supp. 1969) (10 days) ; PA. STAT. tit. 50, $\$ \$ 2063$ (a) (1), 2067 (a), 4403 (1969) (10 days). Provisions are also made for emergency detentions of drug users. E.g., PA. STAT. tit. $50, \S 4405$ (1969). Statutory provisions for involuntary commitment of alcoholics are not as common as those for mental defectives nor for drug addicts, but they do exist in some jurisdictions. See MAss. ANN. Laws ch. 123, $\$ 62$ (Supp. 1969). Some statutes authorize voluntary confinement followed by the usual specified period when the inmate may be involuntarily held. See, e.g., WASE. REV. CODE ANN. \$70.96.100 (1962) (any voluntary inmate adjudicated incompetent may be confined for up to 120 days following his written request for release).

Statutes commonly provide for the temporary care (confinement) of both drug users and alcoholics. See, e.g., MASs. ANN. LAws ch. 123, \$80 (1965).

39 See Roberts v. Paine, 124 Conn. 170, 199 A. 112 (1938). The former patient sued the hospital to recover damages for false imprisonment. Upholding a verdict for the hospital, the court noted: "The finding is barren of any facts other than that the plaintiff made known to the officers of the [hospital] his desire to leave, and this in itself is not enough to impose upon it the duty to inform him as to the method he should follow to secure his release." Id. at 176, 199 A. at 115 .

${ }^{40}$ Culpability as used here refers either to the presence of some fault actionable in tort or to the unconstitutionality of the official's act. 
approach is untenable for several reasons. First, error may flaw a criminal or civil proceeding and no one be at fault. Thus, if compensation is to wait on culpable acts giving rise to a cause of action in tort for damages, many erroneous confinements will go unremedied. Second, as will be discussed, ${ }^{41}$ damage suits against government agents often face nearly insuperable obstacles.

The culpability of the agent causing the confinement does not alter the essential injury of the innocent prisoner: the fact and extent of the injury should be of controlling significance rather than the degree of fault of the government agent. Not the agent, but the government itself, justifying the mistaken exertion of power over the individual, should redress the injury. Were the erroneous confinement exclusively the result of fortuity, or even of the acts of private citizens, then the government's obligation would appear gratuitous and might be likened to its obligation to compensate victims of crime. ${ }^{42}$ But an erroneous confinement from the point of view of the government is more accurately characterized as a quid pro quo. ${ }^{43}$ Any system providing for confinement is only as perfect as those who design and operate it. Certainly it is more important that there be an imperfect system, with its inherent risks of hardship, than that no system exist and the community be left unprotected from lawlessness. ${ }^{44}$ But the privilege embodied in the license to operate an imperfect system should not be absolute. In reference to the criminal law system, Professor Borchard stated:

[I]n the operation of any great undertaking, such as the management of a large industry or the administration of the criminal law, there are bound to be a number of accidents .... Where the common interest is joined for a common end-maintaining the public peace by the prosecution of crime-each individual member being subject to the same danger (erroneous conviction), the loss when it occurs should be borne by the community as a whole and not by the injured individual alone. ${ }^{45}$

Liability for erroneous confinements-"special sacrifices" ${ }^{46}$ demanded by the government of its citizens, who acquiesce in the use of an

41 Notes 59-95 infra \& accompanying text.

42 See Cameron, Compensation for Victims of Crime:The New Zealand Experiment, 12 J. PuB. L. 367, 370 (1963) (compensation an act of charity justified by a sense of obligation toward the victim) ; Childres, supra note 7 , at 457 (compensation necessary because many people cannot afford private insurance).

43 See note 14 supra.

44 See Jennings, Tort Liability of Administrative Officers, 21 MrNN. L. REv. 263, 269 (1937).

45 Borchard, State Indemnity for Errors of Criminal Justice, 21 B.U.L. REv. 201, 208 (1941).

46 Borchard, Theories of Governmental Responsibility in Tort, 28 CoLum. L. Rev. 734, 774 (1928): 
imperfect instrumentality-should be imposed upon the government not because it was at fault by conventional standards but as a matter of social adjustment. ${ }^{47}$

Although the immediate problem of incarceration is obviously ended by the prisoner's release, freedom from imprisonment is inadequate compensation and does not satisfy the government's liability. Release simply reverses the course of the tragedy; it does nothing to repair the damage. The liability should be satisfied by monetary compensation. Substantial legal ${ }^{48}$ as well as social adjustments must be made to effect a satisfactory return to the community; financial resources available upon release to an average prisoner from the government have been estimated to vary from sixteen to one hundred and twenty dollars. ${ }^{49}$ One-third of federal prisoners polled had no employment during the first month following their release, ${ }^{50}$ and the median cash income for the first month was eighty dollars. ${ }^{51}$

Remarkably, less than ten percent of the former prisoners ascribed their difficulty in acquiring employment to their criminal record. ${ }^{52}$ This indicates that expungement of the criminal record of persons erroneously confined may not alleviate their difficulties in securing adequate employment. An individual forced to forfeit a normally vital and productive period of his life is retarded in his personal, economic, and social progress as compared with his peers. The significance of this disparity cannot be underestimated. Obviously the severity of the loss relates directly to the length of the erroneous confinement. But even a relatively short confinement cannot be ignored: as one commentator has said:

$[N]$ o exercise of state power is more feared than interference with the freedom to come and go; and particularly when the detention is deliberate the law's concern with remedial action is great. $^{63}$

More specifically, unwilling confinement has been described as "the most serious deprivation of individual liberty that a society may

[S]pecial sacrifices imposed upon or borne by the individual in the pursuit of the common aim, the administration of the public service, should be spread over the community as a whole instead of resting . . . solely upon the injured individual.

47 W. Prosser, The Law of Torts 509 (3rd ed. 1964); see Pound, The End of Law as Developed in Legal Rules and Doctrines, 27 HARv. L. REv. 195, 233 (1914).

48 See, e.g., Damaska, Adverse Legal Consequences of Conviction and Their Removal: A Comparative Study, 59 J. CRIM. L.C. \& P.S. 347,349 (1968). The article recognizes problem areas facing the former prisoner concerning political activity, standing in the community, public office and professional standing, contracts, military matters, and participation in the administraton of justice.

49 D. Glaser, The Effectiveness of a Prison and Parole System 319 (1964).

50 Id. 328.

Id. 341 .

51 Id. 333. Three-eighths of a typical postrelease panel had median debts of $\$ 470$.

$52 I d .356$.

53 L. Jaffe, Judicial Control of Adainistrative Action 250 (1965). 
impose." ${ }^{54}$ Certainly monetary compensation cannot restore the individual to his original position before the erroneous confinement, but it is the most practical means of aiding him to recoup his time and opportunity losses.

Although not a new concept, ${ }^{55}$ strict governmental liability, as the doctrine espoused here is commonly known, has received little application in the area of erroneous confinements. Yet it is more effective than the other two remedial schemes-fault-based tort liability and private bills granting compensation through special legislation-offering either actual or potential governmental compensation. The goal for the remainder of this Comment is to examine these remedies in terms of their effectiveness as a means of compensating victims of erroneous confinement.

\section{REMEDIES}

\section{A. Fault-based Governmental Tort Liability}

The first drawback to a fault-based system of liability in tort is that it must both compensate and admonish. ${ }^{56}$ This often results in what has been termed the "mutual hampering effect" of the attempt "to compensate the plaintiff for one set of reasons, and to punish the defendant for an entirely different set of reasons . . . " 57 The practical result is to diminish the availability of the tort remedy when the extent of the tortfeasor's fault and his victim's injury are significantly out of joint. Even where the "mutual hampering effect" does not foreclose a remedy, "it can only be thru the sheerest accident that the sum which will make the plaintiff whole will also happen to be the proper penalty to bring about the reform of the defendant and act as a deterrent to others." 58 Thus, both objectives are often distorted in accommodation, thereby stifling compensatory relief.

Litigation to redress an erroneous confinement may take the form of a suit either against the official proximately causing the confinement, or against the responsible government. 59 The following discussion analyzes the difficulties with both approaches.

54 Livermore, Malmquist, \& Meeh1, On the Justifications for Civil Commitment, 117 U. PA. L. REv. 75 (1968).

${ }^{55}$ For an explication of some of the fundamental theories underlying the basic notion of strict governmental liability, see Borchard, Theories of Governmental Responsibility in Tort, 28 Colum. L. REv. 734, 742-72 (1928).

56 A. Ehrenzweig, Negligence Without Fault 84 (1951).

57 Morris, Rough Justice and Some Utopian Ideas, 24 InL. L. Rev. 730, 733 (1930).

$58 I d$.

59 In actions for damages, whether or not a suit is against the state (as opposed to the individual official) depends upon whether "the judgment sought would expend itself on the public treasury or domain, or interfere with the public administration." Land v. Dollar, 330 U.S. 731, 738 (1947); accord, Dugan v. Rank, 372 U.S. 609, 620 (1963). 


\section{Suits Against Government Officials}

The most formidable obstacle to relief facing a victim of erroneous confinement derives from the doctrine of sovereign immunity. As a general proposition, the government may not be sued without its consent. $^{60}$ This immunity has been applied to certain government officials, $^{01}$ first to judicial officers and later to other officials exercising a discretionary function. ${ }^{62}$

The immunity of select government officials from suit has been said to be designed to assure their freedom "to exercise their duties unembarrassed by the fear of damage suits" so that they might carry out the "fearless, vigorous, and effective administration of policies of government." ${ }^{33}$ First, the mantle of immunity will cover an official so long as he acts within the scope of his authority, ${ }^{64}$ a phrase encompassing all but the most private of activities; that is, those which look to the state for none of their efficacy. ${ }^{65}$ Second, immunity is granted federal and state officials ${ }^{66}$ whose activities require an exercise of discretion ${ }^{67}$-the boundaries of which may frequently define the official's scope of authority.

60 Kawananakoa v. Polyblank, 205 U.S. 349, 353 (1907) ; United States v. Lee, 106 U.S. 196, 207 (1882) (dictum); Gibbons v. United States, 75 U.S. (8 Wall.) 269,275 (1868).

61 See $3 \mathrm{~K}$. Davis, Admintstrative Law Treatise $\$ \$ 26.01-26.07$ (1958); F. HARPER \& F. JaAres, The LAW of TORTS $\$ \$ 29.8-29.10,29.11029 .15$ (1956); L. JAFFe, supra note 53, at 213-60; W. Prosser, supra note 47, at 1013-19.

$623 \mathrm{~K}$. DAvis, supra note 61 , at $\$ 26.01$.

63 Barr v. Matteo, 360 U.S. 564, 571 (1959) (governmental immunity as absolute defense to libel action against federal executive officer); see Booth v. Fletcher, 101 F.2d 676, 680 (D.C. Cir. 1938), cert. denied, 307 U.S. 628 (1939).

64 E.g., Bradley v. Fisher, 80 U.S. (13 Wall.) 335, 347 (1871); Norton v. McShane, 332 F.2d 855, 857 (5th Cir. 1964); Gregoire v. Biddle, 177 F.2d 579, 581 (2d Cir. 1949), cert. devived, 339 U.S. 949 (1950).

65 Chief Judge Learned Hand has said of the scope of authority:

What is meant by saying that the officer must be acting within his power cannot be more than that the occasion must be such as would have justified the act, if he had been using his power for any of the purposes on whose account it was vested in him.

Gregoire v. Biddle, 177 F.2d 579, 581 (2d Cir. 1949), cert. denied, 339 U.S. 949 (1950). 60 With few exceptions, distinctions between federal and state precedent in this area are insignificant. Professor Jaffe has written:

[N]o distinction has ever been explicitly recognized in the cases between suits against state and against federal officers, since rationalization has proceeded in terms of an abstract sovereign equally applicable to both types of case.

L. JAFFE, supra note 53, at 216-17.

67 See, e.g., Barr v. Matteo, 360 U.S. 564, 571-78 (1959) (Acting Director of the Office of Rent Stabilization); Norton v. McShane, 332 F.2d 855, 859-62 (5th Cir. 1964) (first assistant to the Assistant Attorney General and a Deputy U.S. Marshall); Bershad v. Wood, 290 F.2d 714, 716-17 (9th Cir. 1961) (a district director and collection officer of the Internal Revenue Service); L. JAFFE, supra note 53, at 240-47. In Ove Gustavsson Contracting Co. v. Floete, 299 F.2d 655, 659 (2d Cir. 1962), cert. denied, 374 U.S. 827 (1963), Judge Medina referred to discretionary-based immunity, saying:

There is no litmus paper test to distinguish acts of discretion . . . and to require a finding of "discretion" would merely postpone, for one step in the process of reasoning, the determination of the real question-is the act 
The most important class of immune officials is composed of the judiciary. ${ }^{68}$ (Exceptions to immunity arise on those infrequent occasions when a judicial officer acts wholly without jurisdiction. ${ }^{69}$ ) Judicial immunity of judges often forecloses relief in actions for tortious confinements because judicial activity is often the proximate cause of the incarceration. The extension of immunity to quasi-judicial officers, ${ }^{70}$ especially prosecutors, ${ }^{71}$ has further reduced the likelihood of telief. Finally, immunity has been granted to judicial and quasi-judicial officers in suits brought under the Civil Rights Act ${ }^{72}$ as well.

The doctrine of official immunity, while not totally consistent in its application, has prevented many victims of clearly invalid confinements from obtaining relief. It has been held, for example, that no action will lie against the judge in favor of men incarcerated as a result of erroneous procedures ${ }^{73}$ for errors in judgment resulting in improper detention after arrest, ${ }^{74}$ for mistakes concerning the weight of the evidence presented, ${ }^{75}$ nor for erroneous inferences drawn from testi-

complained of the result of a judgment or decision which it is necessary that the Government official be free to make without fear or threat of vexatious or fictitious suits and alleged personal lability?

68 See, e.g., Bradley v. Fisher, 80 U.S. (13 Wall.) 335, 347-54 (1871) ; Folland v. Lutz, 194 Kan. 712, 715-16, 401 P.2d 1015, 1019 (1965) ; DeWitt v. Thompson, 192 Miss. 615, 625, 7 So. $2 \mathrm{~d}$ 529, 531 (1942) ; Moore v. Cotton, 94 N.H. 387, 388, 54 A.2d 167, 168 (1947). See generally Thompson, Judicial Immutnity and the Protection of Justices, 21 Mod. L. Rev. 517 (1958).

69 See, e.g., Farish v. Smoot, 58 So. $2 d$ 534, 537-38 (Fla. 1952) (judge liable for ordering arrest of prisoner who was released on a valid habeas corpus petition); Vickrey v. Dunivan, 59 N.M. 90, 94, 279 P.2d 853, 855 (1955) (conviction for conduct not prohibited by municipality's ordinance) ; McKelvey v. Marsh, 63 App. Div. 396, 400,71 N.Y.S. 541, 543 (1901) (city magistrate issued warrant on clearly insufficient information); Kaptur v. Kaptur, 50 Ohio App. 91, 93, 197 N.E. 496, 497 (1934) (complaint set forth no charge of the commission of a crime). Even this rare exception to judicial immunity has been qualified by decisions holding it insufficient to deprive a judge of immunity simply because his acts constituted an excessive or erroneous exercise of jurisdiction, e.g., Holland v. Lutz, $194 \mathrm{Kan} .712$, 717-18, 401 P.2d 1015,1021 (1965), or involved the decision that he had jurisdiction when in fact he had none, Tedford v. McWhorter, 373 S.W.2d 832, 834 (Tex. Civ. App. 1963).

Furthermore, even in the exceptional cases when a judge is held not immune, he will probably prevail in the litigation. Referring to a hypothetical judge-defendant, Professor Jaffe has written:

Neither he, himself, nor a later tribunal will be inclined to characterize his action as arbitrary. The judge's protection is in part a reflection of his exalted station, in part the complement of the fact that the individual has effective protection in the procedure and formalities of the judicial system.

L. JAFFE, supra note 53, at 242.

70 See, e.g., Barr v. Matteo, 360 U.S. 564, 569-76 (1959) ; L. JAFFE, siprra note 53, at $242-43$.

71 See, e.g., Yaselli v. Goff, 12 F.2d 396, 404-06 (1926), aff'd, 275 U.S. 503 (1927) (per curiam); Agnew v. Moody, 330 F.2d 868, 869 (9th Cir. 1964); Gregoire v. Biddle, 177 F.2d 579, 581 (2d Cir. 1949), cert. denied, 339 U.S. 949 (1950).

72 See Pierson v. Ray, 386 U.S. 547, 554-58 (1967) (judges immune, and the defense of good faith and probable cause available to policemen in actions under 42 U.S.C. $\$ 1983$ (1964)). See also L. JAFFE, supra note 53, at 242-43.

73 DeWitt v. Thompson, 192 Miss. 615, 625, 7 So. 2d 529, 531 (1942); Stahl v. Currey, 135 Ohio St. 253, 258-62, 20 N.E.2d 529, 532-33 (1939).

74 Comstock v. Eagleton, 11 Okla. 487, 494-95, 69 P. 955, 957 (1902), appeal dismissed, 196 U.S. 99 (1905) (no cause of action although judge exceeded his authority). 75 Johnson v. Morton, 94 Mich. 1, 5-6, 53 N.W. 816, 817 (1892). 
mony. ${ }^{76}$ In Broom v. Douglas, ${ }^{77}$ a justice of the peace was held immune from suit notwithstanding his issuance of an arrest warrant on the basis of an affidavit wholly insufficient to charge a criminal offense. ${ }^{78}$ An error not strictly part of the judicial procedure does not remove the immunity. In Bujaki v. Egan, ${ }^{\mathbf{7 9}}$ for example, no damages were awarded when a prisoner was not freed because the release order from the judge was not communicated to the jailor.

The relevance of official immunity may depend to an extent on the nature of the cause of action. Suits to redress erroneous confinements are usually brought under two tort theories. The first, false imprisonment, refers to an arrest or confinement without legal authority, the essence of the tort being "the perversion of proper legal procedure." ${ }^{80}$ The second, malicious prosecution, focuses on the motives of the defendant in using his authority to effect the confinement when the process or use of authority is otherwise valid. ${ }^{81}$ Against police officers, the largest class of officials without nearly absolute immunity, false imprisonment will usually be a valid cause of action, ${ }^{82}$ but actions for malicious prosecutions often fail. ${ }^{83}$ This pattern is also

70 Marks v. Sullivan, 9 Utah 12, 17-18, 33 P. 224, 225-26 (1893) (magistrate issued defective warrant based on affidavit).

77175 Ala. 268, 57 So. 860 (1912).

78 Id. at 283, 57 So. at 865 . The case of Gibson v. Reynolds, 172 F.2d 95 (8th Cir. 1949), offers another example of quasi-judicial immunity. Here, plaintiff's "desertion" following an improper draft classification led to his arrest and an erroneous confinement. His suit failed because members of the local draft board were held immune. See Papagianakis v. The Samos, 186 F.2d 257 (4th Cir. 1950), cert. denied, 341 U.S. 921 (1951) (immigration officials held immune from suit by alien who allegedly was erroneously detained aboard ship).

79237 F. Supp. 822 (D. Alas. 1965).

80 W. Prosser, supra note 47 , at 853.

81 Id.

82 See, e.g., Craig v. Cox, 171 A.2d 259, 262 (D.C. Mun. Ct. of App. 1961), $a f f^{\prime d}, 304$ F.2d 954 (D.C. Cir. 1962) ; Boies v. Raynor, 89 Ariz. 257, 260, 361 P.2d 1,3 (1961); Ulibarri v. Maestas, 74 N.M. 517, 520-21, 395 P.2d 238, 240 (1964); Kilcup v. McManeus, 64 Wash. 2d 771, 777-78, 394 P.2d 375, 379 (1964).

83 The authorities on the amenability of police officers to suit for malicious prosecution appear divided, with the law developing in favor of extension of the immunity to the police in this area. For cases favoring police immunity, see Springfield v. Carter, 175 F.2d 914, 918 (8th Cir. 1949) (building inspector); Laughlin v. Garnett, 78 App. D.C. 194, 138 F.2d 931 (D.C. Cir. 1943), cert. denied, 322 U.S. 738 (1944) (police) ; Coverstone v. Davies, 38 Cal. 2d 315, 321-23, 239 P.2d 876, 879-81 (1952); White v. Towers, 37 Cal. $2 \mathrm{~d}$ 727, 729-33, 235 P.2d 209, 211-214 (1951) (fish and game investigator); Dawson v. Martin, 150 Cal. App. 2d 379, 382-83, 309 P.2d 915, 917-18 (1957) (fire and building inspector) ; Bromund v. Holt, 24 Wis. 2d 336, 341-46, 129 N.W.2d 149, 152-55 (1964) (police and pathologist employed by coroner). See also W. Prosser, supra note 47, at 856; Annot., 28 A.L.R.2d 646, 649 (1953).

Cases holding law enforcement officers liable for malicious prosecution include: Motley v. Dugan, 191 S.W.2d 979, 981-82 (St. Louis Ct. App. 1945) (township constable); Earl v. Winne, 14 N.J. 119, 132-35, 101 A.2d 535, 542-44 (1953) (detectives); Vesey v. Connally, 112 Ohio App. 225, 226, 175 N.E.2d 876, 877 (1960) (police) ; Atkinson v. Burmingham, 44 R.I. 123, 127, 116 A. 205, 207, 36 A.I.R. 366, 369 (1922) (police chief) ; Kidd v. Reynolds, 20 Tex. Civ. App. 355, 358, 50 S.W. 600, 601 (1899) (town marshall). See also Note, Torts-Malicious Prosecution-Public Officers, 32 N.C.L. Rev. 360, 36466 (1954). 
found in suits brought under the Civil Rights Act. ${ }^{84}$

Monroe v. Pape ${ }^{85}$ made clear that the Civil Rights Act ${ }^{86}$ "should be read against the background of tort liability that makes a man responsible for the natural consequences of his actions." 87 At least one commentator has suggested that the common law remedies and the Civil Rights Act damage remedies are becoming coterminous. ${ }^{88}$ The Supreme Court, however, recently held that the common law immunities of judicial and quasi-judicial officers continue under the Civil Rights Act, ${ }^{89}$ as do many of the common law defenses such as good faith and probable cause in false imprisonment actions against police officers. ${ }^{90}$ Thus, although the Civil Rights Act provides a federal forum and a constitutional nomenclature for private suits to redress erroneous confinements, it remains questionable the extent, if any, to which police are susceptible to suit, at least in the context of the usual erroneous confinement situation.

Even if a victim of an erroneous confinement can find a nonimmune defendant and overcome such defenses as legal justification in false imprisonment ${ }^{91}$ or probable cause and the absence of malice in malicious prosecution, ${ }^{92}$ he may nonetheless find himself suing a judgment-proof official..$^{93}$ In addition, the cultural and economic background of many victims of erroneous confinement makes it unlikely that they will be able to afford to bring suit or, once in court, that they will elicit jury sympathy. ${ }^{94}$

The tortious acts of officials cause only a portion of all erroneous confinements. Many others, resulting from nontortious errors by officials and the conduct of private parties, promise similarly slight prospects for recovery. ${ }^{95}$ In sum, even the few well-situated plaintiffs

84 On the availability of the Civil Rights Act, 42 U.S.C. $\$ 1983$ (1964), for providing relief for malicious prosecution, the courts are divided. Compare Curry v. Ragan, 257 F.2d 449, 450 (5th Cir.) (per curiam), cert. denied, 358 U.S. 851, rehearing denied, 358 U.S. 914 (1958) (no action available for malicious prosecution), and Bradford v. Lefkowitz, 240 F. Supp. 969, 97475 (S.D.N.Y. 1965) (no cause of action), with Nesmith v. Alford, 318 F.2d 110, 122-26 (5th Cir.), rehearing denied, 319 F.2d 839 (1963) (per curiam), cert. denied, 375 U.S. 975 (1964) (malicious prosecution constitutes violation of civil rights provisions).

85365 U.S. 167 (1961).

8642 U.S.C. $\$ 1983$ (1964).

87365 U.S. at 187.

88 See Shapo, Constitutional Tort: Monroe v. Pape, and the Frontiers Beyond, 60 Nw. U.L. REv. 277, 320-29 (1966).

89 Pierson v. Ray, 386 U.S. 547, 555 (1967).

$90 \mathrm{Id}$. at 557.

91 See W. Prosser, supra note 47, at 61.

$92 I d$. 859-68.

93 Foote, Tort Remedies for Police Violations of Individual Rights, 39 Mrns. L. Rev. 493, 499 (1955). The courts have held that the government does not have a duty to exact a bond (on which injured persons might sue) from a police officer. W. Prosser, supra note 47, at 1006.

94 Foote, supra note 93 , at 500 .

95 For example, the testimony of a witness in a prior criminal proceeding may not be admissible in a subsequent action against the witness for malicious prosecution. See Annot., 81 A.L.R. 1119, 1124-25 (1932). 
in suits against government officials must anticipate substantial obstruction along the path to adequate relief for erroneous confinement.

\section{Suits Against the State}

The prospects for recovery directly from the government for the actionable wrongs of its agents are not significantly more encouraging. Sovereign immunity, ${ }^{96}$ a judicially created concept ${ }^{97}$ appearing in the federal and some state constitutions, ${ }^{98}$ is the initial, and in some jurisdictions insuperable, barrier to redress. Although governmental liability for erroneous confinements is foreclosed when the immunity is absolute, ${ }^{99}$ some jurisdictions have partially waived their immunity, providing a potential for redress.

Waiver of sovereign immunity has been accomplished through both judicial abrogation and legislative waiver. ${ }^{100}$ Largely as a result of judicial abrogation, sovereign immunity has been described as "on the run." 101 During the period 1957-65, judicial action alone in thirteen jurisdictions opened large areas once immune from suit. ${ }^{102}$ In most cases judicial abrogation simply presages subsequent legislation defining the new liability. ${ }^{103}$

${ }^{96}$ See generally $3 \mathrm{~K}$. DAvIs, supra note 61 , at $\$ \$ 25.01-25.17 ; 2$ F. HARPER \& F. JAMrES, stlpra note 61 , at $\$ \$ 29.1-29.7,29.11-29.15$; L. JAFFE, supra note 53 , at 213-60; W. PROSSER, sipra note 47, at 996-1013.

$973 \mathrm{~K}$. Davrs, supra note $61, \$ 25.01$.

98 U.S. Const. amend. XI, provides that no state may be sued by a citizen of another state in federal court. State constitutions containing such provisions typically provide that the state shall never be made a defendant in any court of law or equity. See, e.g., AlA. Const. art. I, § 14; ARK. Const. art. V, § 20; ILL. Const. art. IV, §26; W. VA. CoNst. art. VI, §35.

90 Until recently, more than half the states were at most occasionally responsible for their torts, and in several of those jurisdictions responsibility was almost never undertaken. See Leflar \& Kantrowitz, Tort Liability of the States, 29 N.Y. U.L. REv. 1363, 1407 (1954). Political subdivisions within the state are also generally immune. See 2 F. HARPER \& F. JAMES, supra note 61 , at $\$ 29.11$,

100 For the purpose of this section on fault-based tort liability, only certain legislative action is relevant. Generally, governmental responsibility for injuries caused by its agents may be based on the following types of legislative action: (1) Legislation creating in the courts a right of action against the state. (2) Legislation creating a right to have the courts or another body recommend to the legislature that it pass private relief bills on particular occasions or legislation delegating to an administrative agency the duty to hear claims. This type of legislation takes two forms: (a) It may be used as a device to avoid state constitutional provisions that proscribe suits against the state. Legislative approval of damage awards here would be a mere formality after the initial enactment; and (b) It may result in an actual exercise of legislative discretion in making awards in response to judicial or agency recommendations. (3) Legislation in the form of private bills which are the result of relatively independent legislative discretion. See 2 F. HARPER \& F. JAMres, supra note 61 , at $\$ 29.4 \mathrm{n} .3$; Leflar \& Kantrowitz, supra note 99 , at $1407-08$. Types (1) and (2) (a) are within the area of fault-based tort liability, while discussion of types (2) (b) and (3) is properly reserved for the analysis of private bills.

1013 K. Davis, supra note 61, at $\S 25.1$ (Supp. 1965).

$102 I d$.

103 See Van Alstyne, Govermmental Tort Liability: A Public Policy Prospectus, 10 U.C.L.A.L. REv. 463, 463-72 (1963) ; Van Alstyne, Governnental Tort Liability: Judicial Lazenaking in a Statutory Milieu, 15 STAN. L. REv. 163, 163-65, 178-79 (1963). 
Despite statutory waiver, nearly all aspects of official immunity frustrating actions against officials likewise impair the compensatory potential of action against the state. Even after the state has generally waived immunity, the various immunities protecting officials from suit are often assimilated into the concept of governmental liability. Thus the government is often immune from suit whenever the acting official would be immune. For example, New York has waived its immunity from suit, but refuses, on the basis of official immunity, to accept liability for the acts of its judicial officers. ${ }^{104}$ At least one court has said that government immunity is identified with official immunity because the policy considerations in each case are similar: that is, public officials may fail to pursue their duties vigorously if they must worry that their actions may lead to liability of their employer. ${ }^{105}$ In addition, statutes making the government liable for the torts of its agents commonly except cases in which officials have exercised a "discretionary" function. ${ }^{106}$ Thus recovery is foreclosed in most suits against the state for tortious erroneous confinement because the culpable conduct of judicial and quasi-judicial officials is not actionable.

The most striking vestige of official liability law in governmental liability is its fault-based nature. Many state statutes, ${ }^{107}$ as well as the Federal Tort Claims Act, ${ }^{108}$ limit governmental liability solely to redressing injury caused by what would otherwise have been an actionable wrong if done by a private individual. Thus the plaintiff encounters difficulties and expense in proving fault and proximate cause similar to those experienced by plaintiffs in actions against private individuals. Furthermore, he must often attempt to analogize private tort situations to acts peculiar to governmental functions, such as the

104 See, e.g., Smith v. State, 26 App. Div. 2d 974, 274 N.Y.S.2d 738 (1966) (mem.) ; Cole v. State, 19 Misc. 2d 589, 196 N.Y.S.2d 775 (1959). (1966).

105 See Creelman v. Svenning, 67 Wash. 2d 882, 88485, 410 P.2d 606, 607-08

106 Most of the statutes follow the provision of the Federal Tort Claims Act, 28 U.S.C. \$2680(a) (1964), which excludes claims based upon "the exercise or performance or the failure to exercise or perform a discretionary function or duty on the part of a federal agency or an employee of the Government, whether or not the discretion involved be abused." For similar provisions in state statutes, see Alaska Stat. $\$ 09.50 .250$ (1) (Cum. Supp. 1969); Cal. Gov't Code $\$ 820.2$ (West 1966); HawaII Rev. Laws \$662-15(1) (1968); Iowa Code ANN. §25A.14(1) (1967); Minn. Stat. AnN. \$ 466.03(6) (1963); Nev. Rev. Stat. \$ 41.032 (1965); WIS. Stat. ANN. \$895.43(3) (1966) (excluding injury caused by exercise of judicial and quasi-judicial functions).

107 See Hawair Rev. Stat. §662-2 (1968); Irt. Ann. Stat. ch. 85, § 1-204 (Smith-Hurd 1966); Iowa Code ANN. §25A.2(4) (1967); NEv. Rev. Stat. \$41.031 (1965); N.Y. Judiclary-CT. CL. Act $\$ 8$ (McKinney 1963); N.C. Gen. Stat. §143-291 (Cum. Supp. 1969); Utar Code AnN. \$63-30-10 (Supp. 1967); Wash. Rev. Code AnN. $\$ \$ 4.92 .090,4,96.010$ (Supp. 1969).

10828 U.S.C. \$\$2671-2680 (1964), as amended, (Supp. IV, 1969); see Feres v. United States, 340 U.S. 135, $141-42$ (1950); cf. United States v. Page, 350 F.2d 28, 34 (10th Cir. 1965), cert. denied, 382 U.S. 979 (1966). 
power to arrest and imprison ${ }^{109}$ or to call persons to military service. ${ }^{110}$ Even under the conditions most conducive to a tort action against the state, governmental liability is nonetheless limited to fault; thus victims of nonculpable erroneous confinements have no action in tort. And even if fault is present, in some states the statutes expressly exclude the government from liability for false imprisonment, false arrest, malicious prosecution, and abuse of process - the torts most likely to lead to erroneous confinements. ${ }^{111}$

As discussed above, two primary limitations on liability apply to suits against officials. First, they are responsible only for their legally culpable acts-that is, those performed beyond the scope of their authority. And second, because "discretionary" activities immunize officials from suit, they are not liable for those acts no matter how culpable. Why these limitations on individual liability should be applied to governmental liability is not entirely clear.

Professor Jaffe suggests that application of official immunities to the state presents no anomaly because "despite innumerable statements to the contrary, the immunity is not in any realistic sense a device to protect the officer, but rather . . . it expresses, even if subconsciously, the conclusion that the plaintiff should not recover at all." ${ }^{112}$ And, because the immunities of the officer and of the state are nearly identical,"113 "the question of immunity has become and should become basically whether in all the circumstances the plaintiff is entitled to monetary relief." 114 Taken broadly, Professor Jaffe's statement leads to the conclusion that, because the great majority of victims of erroneous confinement do not recover, the state has determined that they are not worthy of compensation. Professor Jaffe himself, however, would probably reject this conclusion in the case of erroneous confine-

109 Certainly the power to arrest and imprison is one of those activities which is unique to a government. But it is not so unique as to justify the invocation of sovereign immunity to give the government complete freedom to make arrests, even careless ones.

Mikva, Sovereign Immunity: In a Denocracy the Emperor Has No Clothes, 1966 U. IIL. L.F. 828, 839-40 (1966).

110 In Small v. United States, 219 F. Supp. 659 (D. Del. 1963), the plaintiff, erroneously called to military service, was denied relief under the Federal Tort Claims Act, 28 U.S.C. $\$ 2674$ (1964), because of the lack of a private analogy to that exercise of governmental power.

111 Federal Tort Claims Act, 28 U.S.C. $\$ 2680(\mathrm{~h})$ (1964); AlAsKA STAT. $\$ 09.50 .250$ (3) (Cum. Supp. 1969) ; CAL. GOV'T CoDE $\$ \$ 820.4,856 a$ (West 1966) (the former section excludes claims for false arrest and false imprisonment, while the latter excludes claims based upon determinations by officials of whether or not to confine an individual for mental illness or drug addiction); HawaII Rev. STat. \$662-15(4) (1968); IrL. ANN. Stat. ch. 85, \$\$ 6-105 to 6-107 (Smith-Hurd 1966) (excluding claims concerning determinations to commit the mentally ill and drug addicts) ; IowA CODE ANN. \$25A.14(4) (1967); UTAF CODE ANN. \$§ 63-30-10(2), (5), (10) (Supp. 1967) (the last subsection excludes claims arising "out of the incarceration of any person in any state prison, county, or city jail or other place of legal confinement. ...").

112 L. JAFFE, supra note 53, at 235.

113 Id.

$114 I d$. 
ment, for he has admitted that the breadth of official privilege has been tolerable only because, in cases of severe injury, the gravity of the injury may override the presumption against recovery. ${ }^{115}$ Furthermore, he has recognized erroneous confinement as an injury exceptional in its severity. ${ }^{116}$

Perhaps the single fault-based system defining the individual liability of government officers was transferred to define the scope of governmental liability as a reflection of the appeal of an existing body of tort law to the nascent field of governmental liability, or even of a fixation with notions of fault pervading nearly the entire spectrum of present-day tort law. Whatever the reason, the emerging law of governmental liability inherited all the practical difficulties of reconciling the competing influences of deterrence, compensation, and other rationales relevant to the proper scope of state liability ${ }^{117}$ within the single remedial system of fault-based liability.

The most reasonable conclusion to draw from this failure to reach the problem of erroneous confinement is not that the government has decided that the injury is undeserving of compensation, but that the government has determined that erroneous confinements should not be redressed by a system of fault-based tort liability. And because nearly all tort remedies are conceived within the system of fault-based liability, the absence of a remedy there usually indicates that no remedy is available. Recognizing this, Professor Ehrenzweig asked: "Why is it that this struggle between an injurer's and the injured's law of torts has, up to the present time, been fought within a law of fault liability?" 118 In answer, he suggested a different approach:

[T] he fault theory has been maintained, I believe, as the governing theory of tort law because the only alternative has too often been seen in a rule of unrestricted liability for all causation.

[S]trict liability for all causation is not the only alternative, but . . . fault liability for harm foreseeably caused by reprehensible conduct can be, and as to enterprise risks has largely been, replaced by a liability for "negligence [liability] without fault" for harm typically caused by lawful conduct. ${ }^{110}$

115 Id. 245.

116 Id. 250.

117 Professor Van Alstyne offers six general policy considerations leading to rationally different tort liability consequences of governmental action: (1) the degree of fault in the governmental activity; (2) the degree of risk of harm from the activity; (3) practical alternatives, if any, to liability; (4) the deterrent effect of such liability; (5) the degree of public asssumption of the risks of the activity; and (6) the potentiality of such liability to act as a deterrent to, or interference with, socially desirable governmental activities. Van Alstyne, Governmental Tort Liability: A Public Policy Prospectus, 10 U.C.L.A.L. Rev. 463, $472-532$ (1963).

118 A. EhrenzWeIG, supra note 56, at 13.

119 Id. 14. 
Professor Ehrenzweig's suggestion does not envision a single remedial system, but rather, employment of an additional system of liability without fault if a recurring injury of a severe quality is typically caused by unlawful conduct. The following sections consider remedies not necessarily based upon the culpability of the official causing the incarceration.

\section{B. Private Bills in the Legislature}

The legislature (federal or state) will often remedy a particular injury by passing a private bill authorizing a special appropriation to the injured individual. The remedy may take one of at least three different forms, depending on the jurisdiction: (1) the legislature may consider the claim directly; (2) claims may be presented to administrative authorities for recommendations or determinations before they are presented to the legislature; and (3) the legislature may authorize suits on a particular claim or authorize administrative determination of the claim. ${ }^{120}$ The common element is an ad hoc exercise of legislative discretion in response to each claim.

A generation ago the private bill was reportedly the most prevalent means of satisfying claims against the state. ${ }^{121}$ Today, with the demise of sovereign immunity underway, the private bill is thought to serve more of an interstitial function-to satisfy those "claims of conscience" 122 not remediable by available tort actions.

The private bill has several advantages over purely fault-based tort liability, although the extent to which private bills express a policy of strict liability is uncertain. ${ }^{123}$ The merits of a claim may often be judged in the light of existing but inapplicable tort law, ${ }^{124}$ yet the test has been formulated according to whether the government "controlled or was connected with the physical instrumentality through which damage was done." ${ }^{125}$ Thus, at the very least, private legislation is not limited in all situations to redressing injury caused by wrongful conduct. Neither must the legislature look exclusively to the rules of private tort liability for guidance in deciding the effect of governmental activities for which there may be no private analogue. And finally, the costs of seeking relief through a private bill are usually considerably less than those incurred by prolonged litigation. ${ }^{126}$

$1203 \mathrm{~K}$. Davis, supra note 61 , at $\$ 25.02$.

121 See Nutting, Legislative Practice Regarding Tort Clains Against the State, 4 Mo. L. REv. 1, 16-17 (1939).

122 Gellhorn \& Lauer, Congressional Settlement of Tort Clains Against the United

States, 55 Colum. L. Rev. 1, 32 (1955).

$1233 \mathrm{~K}$. DAvis, supra note 61 , at $\$ 25.02$.

124 Gellhorn \& Lauer, supra note 122, at 13-14.

125 Gellhorn \& Lauer, Federal Liability for Personal and Property Damage, 29 N.Y.U.L. REv. 1325, 1334 (1954).

126 See Note, Administration of Claims Against the Sovereign-A Survey of State Techniques, 68 HARv. L. Rev. 506, 509 (1955). 
Despite the preceding advantages, serious shortcomings in the private bill remedy undermine its utility as a general solution to remedial problems of erroneous incarcerations. To begin with, the procedure does not lead to uniform results. ${ }^{127}$ The reasons for discrepancy are apparent: there is no appeal from legislative action; no opinions are published reciting the reasons for the disposition of claims and affording guidance for future actions; ${ }^{128}$ and, in the federal context, for example, the Subcommittee on Claims will not at present reconsider a vetoed bill absent a material change of facts. ${ }^{129}$ Political pressures may also contribute to the lack of uniformity. ${ }^{130}$ It has even been suggested that occasionally a President will veto an otherwise worthy claim to induce Congress to enact pending general legislation dealing with the subject of the grievance. ${ }^{131}$

Apart from the lack of uniformity, legislative machinery is illequipped to give each of the many claims the investigative scrutiny or the timely disposition a more regular system could offer. The record of one Congress showed that eighty percent of the claims reaching final judgment were more than four years old. ${ }^{132}$ In one case, an Indian boy who had lost his hand and forearm while attending a school operated by the Bureau of Indian Affairs did not receive his compensation for nineteen years. ${ }^{133}$

Finally, the private bill is not available in many jurisdictions. In fact, in at least a dozen states, the constitutions prohibit them, ${ }^{134}$ usually because they do not operate uniformly. ${ }^{135}$

In response to the shortcomings of private bills, one writer observed:

In the long run, emphasis upon general rather than private laws will give larger assurance that the bulk of meritorious claims will be satisfied. ${ }^{136}$

Victims of erroneous confinements provide a class of suitors sufficiently well-defined to justify general legislation. Examination of the fault-based system of tort liability and of the private bill have led to these conclusions: that at least in cases of severe injury, the advisable

127 See E. BorCHARD, supra note 3, at 169, 314.

128 See Note, Private Bills in Congress, 79 Harv. L. Rev. 1684, 1686 (1966).

129 See id. 1693. Budget doubts expressed through the Bureau of the Budget may well result in a veto. Id. 1692 .

${ }^{130}$ See Shumate, Tort Clainis Against State Governments, 9 LaW \& Contemp. Prob. 242, 250-51 (1942).

131 See Gellhorn \& Lauer, supra note 122, at 22-23.

132 Id. 31.

133 Id. 30; see Claim of Mardin, Priv. L. No. 82-278, 65 Stat. 105 (1951).

$1343 \mathrm{~K}$. Davis, supra note 61 , at $\$ 25.02$ \& n.19.

135 For examples of the various types of constitutional provisions designed to secure uniformity of treatment by proscribing private bills, see Nutting, supra note 121 , at $16-17$.

136 Gellhorn \& Lauer, supra note 122, at 25. 
alternative to the former system is an action grounded in strict liability for a select class of injured claimants, and that a general statute is needed to avoid the uncertainties of the private bill. Statutorily imposed strict governmental liability will now be considered.

\section{Strict Governmental Liability}

The theory underlying strict governmental liability has already been discussed. ${ }^{137}$ It can be summarized as follows :

[T] he avowed goal of the absolute liability approach is allocation of loss to the party better equipped to pass it on to the public: the superior riskbearer. . . . The policy . . . should be one of transferring losses only when necessary to achieve the overriding goal of proper loss allocation-when, in other words, the shift is from an inferior to a superior risk bearer. ${ }^{138}$

The risk of severe harm caused by the lawful conduct of the government's agents demands different treatment than is provided under a fault-based system of tort liability. ${ }^{139}$ In addition, the existence of a cohesive class of claimants indicates the utility of a general statute providing for absolute liability, rather than private legislation, and avoids the risk of unrestricted liability for other actions.

Today, five jurisdictions-the federal government, ${ }^{140}$ California, ${ }^{141}$ Illinois, ${ }^{142} \mathrm{New}$ York, ${ }^{143}$ and Wisconsin ${ }^{144}$-have statutes providing for the compensation of persons erroneously confined by the state, regardless of the culpability of its agents. Since redress is based upon these statutes rather than upon any constitutional mandate, ${ }^{145}$ they present merely practical problems of interpretation, and the courts have tended to read their provisions narrowly.

The most significant shortcoming of these statutes is their limited scope. Without exception, they are limited to redressing confinements

137 See text accompanying notes 41-47 sipra.

138 Morris, Hazardons Enterprises and Risk Bearing Capacity, 61 YALE L.J. 1172, 1176 (1952). Strict governmental liability for government activities involving similar risks of harm has become common in many European countries. See Bratholm, supra note 12; Meyer, German Criminal Procednure: The Position of the Defendant in Court, 41 A.B.A.J. 592, 668 (1955); Pock, Systems of Public Responsibility in Szevitzerland, Germany, and Austria, 1966 U. Int. L.F. 1023, 1029, 1051 (1966). See generally Braband, Liability in Tort of the Government and Its Employees: $A$ Comparative Analysis werith Emphasis on Gernan Lawe, 33 N.Y.U.L. REv. 18 (1958); Hink, Governmental Liability for Risk Under French and German Law, 19 RUTGERS L. REV. 472 (1965) ; Hink, Service-Connected Versus Personal Fault in the French Law of Government Tort Liability, 18 RUTGERS L. Rev. 17 (1963); Jacoby, Federal Tort Claims Act and French Law of Governmental Liability: $A$ Comparative Study, 7 VAND. L. REV. 246 (1954).

139 See text accompanying note 119 supra.

14028 U.S.C. $\$ 2513$ (1964).

141 Cat. Penal Code $\$ 4904$ (Supp. 1970).

142 Irl. AnN. Stat. ch. 37, \$439.8(c) (Smith-Hurd Supp. 1960).

143 N.Y. Judiciary Law-CT. Cl. Act. \$9(3-a) (McKinney 1963).

144 Wis. Stat. AnN. \$285.05 (1958).

145 See, e.g., Rigsbee v. United States, 204 F.2d 70, 72 (D.C. Cir. 1953). 
arising out of criminal proceedings. Furthermore, redress is limited to confinement following a conviction-a requirement that automatically excludes all pretrial incarcerations. The California statute is restricted to redress for confinement resulting from a mistaken felony conviction. ${ }^{146}$ Relief has even been withheld under the federal act where an otherwise compensable "conviction" was extinguished by the reviewing officer in a Court Martial proceeding. ${ }^{147}$

The federal statute requires that a claimant obtain a certificate of the court or pardon, indicating not only that the conviction has been "reversed or set aside on the ground that he is not guilty . . . or that he has been pardoned upon the stated ground of innocence," 148 but also that he committed none of the acts charged ${ }^{149}$ and his actions violated no other federal or state offenses. ${ }^{150}$ Issuance of the certificate of innocence has been held to be a matter of discretion for the presiding judge, ${ }^{151}$ and neither a charge dismissed nor a judgment of not guilty is alone enough to upset a judge's determination that the claimant is not "innocent" and does not deserve the certificate. ${ }^{152}$ The state statutes contain similar requirements, and innocence may be required to be shown on the governor's pardon, ${ }^{153}$ at a separate judicial hearing, ${ }^{154}$ or at an administrative proceeding. ${ }^{155}$

The burden of proving innocence in the compensation proceeding has from the start been placed upon the claimant. ${ }^{156}$ The presumption of innocence afforded to the defendant in a criminal proceeding is not applicable in the subsequent statutory compensation proceeding. ${ }^{157}$ One court has stated that, because the United States Supreme Court rarely reverses on the facts, it should be presumed that the claimant committed the acts charged. ${ }^{158}$ If a claimant is released on grounds of actual innocence, his burden is easily met. But if conviction is reversed on procedural grounds, the time elapsed between the original trial and the release may not only leave the prosecutor with sparse evidence upon which to base a new trial, but also similarly impede the claimant's

146 Cal. Penal Code $\S 4900$ (Supp. 1970).

147 See Cox v. United States, 112 F. Supp. 494, $495-96$ (N.D. Cal. 1953).

14828 U.S.C. $\$ 2513(a)$ (1) (1964).

149 The claimant's elements of proof are increased by the requirement that his acts "in connection with his charge" constitute no criminal offense under any jurisdiction. See, e.g., Weiss v. United States, 95 F. Supp. 176, 179-80 (S.D.N.Y. 1951); United States v. Keegan, 71 F. Supp. 623, 638-39 (S.D.N.Y. 1947).

15028 U.S.C. $\$ 2513(\mathrm{a})(2)$ (1964).

151 E.g., Rigsbee v. United States, 204 F.2d 70, 72-73 (D.C. Cir. 1953).

152 United States v. Brunner, 200 F.2d 276, 279-80 (6th Cir. 1952); LeFevre v. Goodland, 247 Wis. 512, 516, 19 N.W.2d 884, 885 (1945).

153 N.Y. Judictary LAW-Cr. CL. ACT \$ 9(3-a) (McKinney 1963).

154 ILl. Ann. Stat. ch. 37, §439.8(c) (Smith-Hurd Supp. 1960).

155 Cal. Penal Code $\$ 4903$ (Supp. 1970); Wis. Stat. Ann. \$285.05(3) (1958).

156 E.g., United States v. Keegan, 71 F. Supp. 623, 636 (S.D.N.Y. 1947) ;

LeFevre v. Goodland, 247 Wis. 512, 515-16, 19 N.W.2d 884, 885 (1945).

157 See, e.g., LeFevre v. Goodland, 247 Wis. 512, 516, 19 N.W.2d 884, 885 (1945). 158 Sinclair v. United States, 109 F. Supp. 529, 531 (Ct. C1.), cert. denied, 345 U.S. 974 (1953). 
attempt to prove his innocence. The point is that errors in past proceedings and a present evidentiary void should not fall upon the shoulders of the claimant in his action for compensation, especially in view of the greater factfinding resources of the government and the difficulty a claimant faces in proving a negative: that he did not commit a certain act. Of course, if the procedural error upon which the release is based does not go to the guilt or innocence (or sanity, if a broader statute were operable) of the claimant, nor to the fairness of the trial, the burden of proof may more permissibly rest upon the claimant. Otherwise the state should accept the burden. The statute could lighten the state's burden by making the record of the first trial admissible and by calling for a preponderance-of-evidence standard rather than proof of guilt beyond a reasonable doubt. ${ }^{159}$

Finally, the state might limit its liability by imposing a ceiling on damages - an absolute upward limit as presently found in most statutes ${ }^{180}$ or graduated ceilings based upon the number of years incarcerated, as in the liberal damage provisions of the Illinois statute. ${ }^{161}$ A more liberal provision might limit recoverable damages to actual pecuniary losses or a fixed multiple thereof. ${ }^{162}$

No matter what limitations the state may employ to restrict its liability, even if its liability may no longer be technically absolute, the strict liability statutes offer a considerably broader purview than existing fault-based systems and the private bill. Recognition by the legislature of the continuous obligation to compensate victims of erroneous confinement, no matter how free from fault the government agents may have been, represents an essential step forward.

\section{CONCLUSTON}

More than forty years ago, Professor Borchard commented on the government's gradual acceptance of tort liability based upon fault, saying:

159 WIS. STAt. ANN. $\$ 285.05(3)$ (1958), places the burden of proving his innocence upon the claimant and insists that it be satisfied "beyond a reasonable doubt," posing a nearly insurmountable obstacle to recovery in cases where reversal of the conviction was based upon procedural grounds.

160 See, e.g., 28 U.S.C. $\$ 2513(\mathrm{e})(1964)(\$ 5,000)$; CaL. Penal Code $\$ 4904$ (Supp. 1970) $(\$ 10,000)$; WIS. STAT. ANN. $\$ 285.05(4)(1958)(\$ 5,000)$. The above ceilings are conservative, and would not adequately compensate most losses suffered from lengthy confinements. In Whitree v. State, 56 Misc. 2d 293, 290 N.Y.S.2d 486 (Ct. Cl. 1968), in an action against the state alleging negligence as the cause of an erroneous confinement of about twelve years, the claimant was awarded $\$ 300,000$ in damages from the state.

161 IrL. Ann. Stat. ch. 37, $\$ 439.8$ (c) (Smith-Hurd Supp. 1960) (5 years or less, $\$ 15,000 ; 5$ to 14 years, $\$ 30,000$; over 14 years, $\$ 35,000)$.

162 See 5 CaItr. Law Revision Comm'n, Sovereign Immunity Study 304 (1963), stating:

A rule of this type, for example, might authorize recovery of costs of medical care and treatment, loss of earnings, impairment of earning capacity and increases in living expenses as a result of the injury sustained by plaintiff; but it would restrict recovery of general damages for pain and suffering, embarrassment and humiliation, and other elements of a nonpecuniary nature . . . . 
We ought to be quite content for the present with this elemental reform, without asking for any such advance as French law has made in looking to the resulting damage rather than to the originating tort. The extreme view that lawful and unlawful invasions of private right rest on the same basis, even if sustainable, must be dismissed as impractical, if not dangerous to an initial reform looking to the compensation of tortious injuries. It may well be, however, that with the education of public opinion to the essential justice of compensating tortious injuries, our social outlook may become broadened to a point where legislatures in enacting measures imposing extraordinary sacrifices on individuals will appreciate the desirability of distributing the special burden among the people as a whole. Thus, police power would assume a less confiscatory aspect and invasions of private rights, now uncompensated, would be acknowledged as incidents of eminent domain. ${ }^{163}$

A generation and a half ago, it may have given cause to rejoice when the state accepted any responsibility for the injurious acts of its agents, even if the emphasis was misdirected toward the quality of the act and as a result the nature of the injury became of secondary importance. But today, enough years have passed and enough victims of erroneous confinements have languished in prisons and asylums to have alerted society to the exigency of compensating them. The inadequacies of fault-based remedies and the uncertain private bills leave a statutory scheme of strict governmental liability as the necessary solution.

Joseph $H$. King, Jr.

163 Borchard, Theories of Governmental Responsibility in Tort, 28 CoLvM. L. Rev. 734, 772 (1928) (emphasis added). The reference to "eminent domain" does not suggest a constitutional mandate compelling liability, but rather implies a voluntary legislative acceptance of responsibility. See notes 14 \& 15 silpra \& accompanying text. 